\title{
Phytochemical Screening and Antioxidant Effect of Ethanol Leaf and Trunk Bark Extracts of Cordyla pinnata (Lepr. Ex A. Rich.) Milne-Redh. (Caesalpiniaceae)
}

\author{
Alioune Dior FALL ${ }^{1 *}$, Serigne Ibra Mbacké DIENG ${ }^{1}$, Abdou SARR', Mbaye DIENG'
}

Alioune Dior FALL ${ }^{1, *}$, Serigne Ibra Mbacké DIENG ${ }^{1}$, Abdou SARR', Mbaye DIENG'

'Laboratory of Pharmacognosy and Botany of the Faculty of Medicine, Pharmacy and Odontology of the Cheikh Anta Diop University of Dakar, SENEGAL.

\section{Correspondence}

\section{Alioune Dior FALL}

Laboratory of Pharmacognosy and Botany of the Faculty of Medicine, Pharmacy

and Odontology of the Cheikh Anta Diop

University of Dakar, SENEGAL.

E-mail: alioune.fall@ucad.edu.sn

History

- Submission Date: 14-08-2019;

- Review completed: 14-10-2019;

- Accepted Date: 14-10-2019.

DOI : 10.5530/pj.2019.11.219

Article Available online

http://www.phcogj.com/v11/i6s

\section{Copyright}

(C) 2019 Phcogi.Com. This is an openaccess article distributed under the terms of the Creative Commons Attribution 4.0 International license.

\begin{abstract}
Introduction: The aim of this study was to investigate the phytochemical composition and the antioxidant effect of ethanol leaf and trunk bark extracts of an African wild plant, Cordyla pinnata (Lepr. Ex A. Rich.) Milne-Redh. C. pinnata is used in Senegalese folk medicine to treat asthenia, spasm and various infections. Methods: The phytochemical investigation of the extracts was done using physico-chemical reactions while antioxidant effect was assessed by DPPH and FRAP assays. Results:Tannins, flavonoids, cardiotonic heterosides and triterpenoids were present in leaf and trunk bark extracts of $C$. pinnata. Meanwhile, anthracenic derivatives were detected in the leaf extract of $C$. pinnata. In DPPH assay, $I C_{50}$ values of the leaf, trunk bark extracts and ascorbic acid were respectively $21.07 \pm 0.11 \mu \mathrm{g} / \mathrm{ml}, 19.53 \pm 0.42 \mu \mathrm{g} / \mathrm{ml}$ and $0.33 \pm 0.11 \mu \mathrm{g} / \mathrm{ml}$. In FRAP assay, the leaf and trunk bark extracts and ascorbic acid reduced significantly ferric ion. Ascorbic acid was seen to be more active in FRAP assay than the leaf and trunk bark extracts of $C$. pinnata. Conclusion: Ethanol leaf and trunk bark extracts of $C$. pinnata had revealed antioxidant activity.
\end{abstract}

Key words: Cordyla pinnata, Phytochemical screening, Antioxidant, Leaf, Trunk bark.

\section{INTRODUCTION}

Cordyla pinnata is a tree commonly found in areas of dry forests and tree savannas from Senegal to Niger, northern Nigeria and northern Cameroon. ${ }^{1}$ Its leaves are imparipinnate with 10 to 20 leaflets alternate to almost opposite. Its trunk is often straight and cylindrical, fissured and scaly at the surface. Trunk bark extracts are used in folk medicine to treat constipation, liver diseases and also as tonic while leaf extracts are reputed for their anthelmintic and antispasmodic properties.

Oxidative stress due to free radicals overproduction has been involved in neurodegenerative disease (Alzeimer and Parkinson diseases), diabetes, cardiovascular disease, atherosclerosis, rheumatoid arthritis etc. ${ }^{2,3}$

There is a paucity about pharmacological and chemical composition investigations of leaf and trunk bark extract of $C$. pinnata. What makes us to assess the phytochemical composition and the free radicals scavenging effect of the leaf and trunk bark extracts of this plant.

\section{MATERIAL AND METHODS}

\section{Plant collection}

Leaves and trunk barks of $C$. pinnata were collected at Gossas (Senegal). The plant was identified and authenticated by Dr William Diatta (Herbarium of the Botanical Garden of the Faculty of Medicine, Pharmacy and Odontology; Cheikh Anta DIOP University of Dakar, Senegal) where voucher specimens were kept. Plant leaves and trunk barks were air dried at room temperature and ground.

An amount of $30 \mathrm{~g}$ of powdered leaves of $C$. pinnata was decocted twice for 30 minutes using $300 \mathrm{ml}$ of ethanol and filtered through Whatman No. 1 filter paper. Ethanol was removed under reduced pressure using a rotary evaporator and lead to the ethanol leaf dried extract. The same process was used to obtain the trunk bark extract.

\section{Phytochemical composition}

To assess the phytochemical composition of the ethanol leaf and trunk bark extracts of C. pinnata, standard phytochemical analyses were used. Chemical tests were carried out on ethanol leaf and trunk bark extracts of the powdered specimens using standard procedures for the detection of alkaloïds (Bouchardat, Valser-Mayer and Dragendorff's reagents tests), tannins (Stiasny test followed by ferric chloride test), flavonoids (Shibata's reaction), saponins (foaming index), sterols and triterpenoids (Liebermann-Buchard reaction), carotenoids (Carr and Price reaction) anthracenic glycosides (Borntraeger test), cardiac glycosides (Baljet, Kedde and Raymond-Marthoud reagents tests), in order to identify the presence of phytoconstituents. ${ }^{4}$

\section{DPPH assay}

The determination of the DPPH free radical scavenging activity of samples was done using the described method. ${ }^{5}$ An ethanol solution of DPPH was prepared by dissolving $4 \mathrm{mg}$ in $100 \mathrm{ml}$ of ethanol. An aliquot of each sample $(0.8 \mathrm{ml})$ at 
appropriate concentration was added to $3 \mathrm{ml}$ of ethanol solution of DPPH.

The ethanol leaf and trunk bark extracts of C. pinnata and ascorbic acid were tested at different concentrations. The absorbance of each sample was measured at $517 \mathrm{~nm}$ after $30 \mathrm{~min}$ using a spectrophotometer. Each experiment was done in triplicate and the absorbance of the initial ethanol DPPH solution did not change after $30 \mathrm{~min}$. The antioxidant activity related to the DPPH free radical scavenging effect was expressed as $\mathrm{IC}_{50}$ (concentration of sample required to scavenge $50 \%$ of free radicals). $\mathrm{IC}_{50}$ values were determined with Statgraphics Plus 5.0 software

\section{Ferric reducing antioxidant power (FRAP) assay}

The ferric reducing power was determined according to the described method. ${ }^{6}$ An aliquot of $0.20 \mathrm{ml}$ of each sample (ethanol leaf and trunk bark extracts of $C$. pinnata) at appropriate concentration was mixed with $0.5 \mathrm{ml}$ of phosphate buffered saline $(0.2 \mathrm{M} ; \mathrm{pH} 6.6)$ and $0.5 \mathrm{ml}$ of $1 \%$ potassium ferricyanide. The mixture was incubated at $50^{\circ} \mathrm{C}$ for $30 \mathrm{~min}$ and $0.5 \mathrm{ml}$ of $10 \%$ trichloroacetic acid was added. After centrifugation for 10 minutes at $3000 \mathrm{rpm}$, the supernatant $(0.5 \mathrm{ml})$ was mixed with distilled water $(0.5 \mathrm{ml})$ and $0.1 \%$ ferric chloride $(0.1 \mathrm{ml})$. The experiments were done in triplicate. Absorbance was measured at 700 $\mathrm{nm}$ using a spectrophotometer and ascorbic acid was used as positive control. Absorbance increasing relatively to that of concentration represented the reducing capacity of tested sample.

\section{Stastical analyses}

Data were expressed as mean \pm SEM. For comparison of results, analyses of variance (ANOVA) were done using Fischer's test. Statistical significance was set at $p<0.05$.

\section{RESULTS}

\section{Extraction}

From $30 \mathrm{~g}$ of dried powdered leaves of C. pinnata, $5.69 \mathrm{~g}$ of dried extract were obtained corresponding to a yield of $18.96 \%$. From the same amount of dried trunk bark, $4.86 \mathrm{~g}$ of dried extract were got yielding $16.2 \%$.

\section{Phytochemical composition}

The main phytochemical groups identified both in the leaf and trunk bark extracts were: tannins, flavonoids, cardiac glycosides, sterols and triterpenoids. As shown in Table 1, Anthracenic derivatives were only met in the leaf extract.

\section{DPPH assay}

According to the Figure 1, all tested samples had shown significative ability to scavenge the free radical DPPH $(p<0.05$ versus negative control). The $\mathrm{IC}_{50}$ value of ascorbic acid $(0.33 \pm 0.11 \mu \mathrm{g} / \mathrm{ml})$ was lowest than those of the ethanol trunk bark extract $(19.53 \pm 0.42 \mu \mathrm{g} / \mathrm{ml})$ and leaf extract $(21.07 \pm 0.11 \mu \mathrm{g} / \mathrm{ml})$ of $C$. pinnata $(p<0.05)$.

\section{FRAP assay}

For ethanol leaf and trunk bark extracts of C. pinnata and ascorbic acid, increasing absorbance were noticed relatively to the concentration variations as shown in Figure $2(p<0.05$ versus negative control). Ascorbic acid had shown better ability to reduce the ferric ion than the plant extracts $(p<0.05)$. However, the trunk bark extract had exhibited similar ferric reducing capacity than the leaf extract at all tested concentrations $(p>0.05)$.

The absorbance values of leaf extract varied from $0.011 \pm 0.005$ at 6.25 $\mu \mathrm{g} / \mathrm{ml}$ to $0.399 \pm 0.012$ at the concentration of $200 \mu \mathrm{g} / \mathrm{ml}$ while those of
Table 1: Phytochemical groups identified in leaf and trunk bark extract of C. pinnata.

\begin{tabular}{lll}
\hline Phytochemical groups & Leaf extract & Trunk bark extract \\
\hline Alkaloids & - & - \\
Tannins & + & + \\
Flavonoids & + & + \\
Sterols and triterpenoids & + & + \\
Saponins & Foaming index $<100$ & Foaming index $<100$ \\
Anthracenic glycosides & & + \\
Cardiac glycosides & + & + \\
\hline
\end{tabular}

+ : presence, - : absence

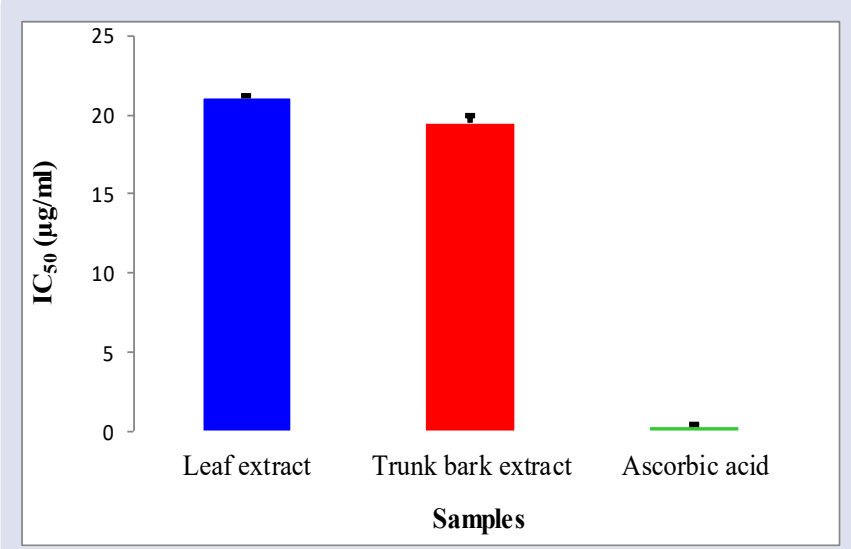

Figure 1: Free radical scavenging effect of tested samples.

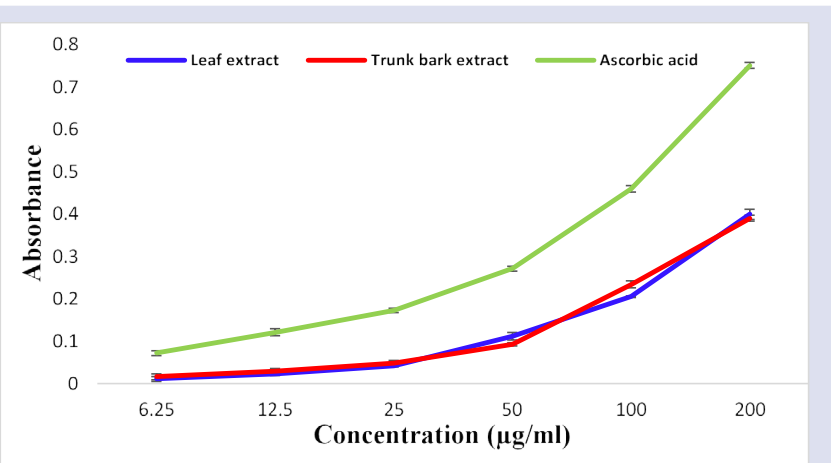

Figure 2: Absorbance increasing of different tested samples.

trunk bark extract were respectively $0.016 \pm 0.007$ and $0.039 \pm 0.007$ at the same concentrations.

For ascorbic acid, the absorbance values increased significantly from the concentration of $6.25 \mu \mathrm{g} / \mathrm{ml}$ to $200 \mu \mathrm{g} / \mathrm{ml}$ (respectively $0.072 \pm$ 0.006 and $0.75 \pm 0.007 ; p<0.05$ ).

\section{DISCUSSION}

The extraction of phtytoconstituents was done using ethanol, a polar solvent, chosen for its ability to extract polar compounds such as polyphenols present in the leaves and trunk barks of $C$. pinnata (tannins and flavonoids). This could explain the extraction yields obtained for the leaf and trunk bark extracts (18.96\% and $16.2 \%$ respectively).

The dried leaflets of $C$. pinnata were reported to contain about $1 \%$ of its weight in flavonoids such as quercetin and kaempferol. ${ }^{7}$

The antioxidant potential of plant extracts can be measured through several in vitro tests. However, for the complexity of plant extracts composition, a single method is not recommended for evaluating their 
antioxidant activity. ${ }^{8}$ DPPH and FRAP methods were cited as reflecting the antioxidant activity of plants extracts. ${ }^{9}$ The DPPH assay measures the ability of the bioactive compound to scavenge free radicals while the FRAP test measures their capacity to reduce metals. DPPH can be reduced by phytoconstituents that are capable for transfering proton or donating hydrogen. ${ }^{10}$

In DPPH method, the ethanolic leaf and trunk bark extracts of $C$. pinnata exhibited significant antioxidant activity $(p<0.05)$.

The ethanol trunk bark extract of C. pinnata $\left(\mathrm{IC}_{50}: 19.53 \pm 0.42 \mu \mathrm{g} / \mathrm{ml}\right)$ had exibited better ability to scavenge the DPPH free radical than that of the leaf extract $\left(\mathrm{IC}_{50}: 21.07 \pm 0.11 \mu \mathrm{g} / \mathrm{ml}\right)(p<0.05)$. Ascorbic acid $\left(\mathrm{IC}_{50}: 0.33 \pm 0.11 \mu \mathrm{g} / \mathrm{ml}\right)$ was seen to be more active than the plants extracts.

The FRAP method is often used to evaluate the reducing power of extracts. At all tested concentrations, ethanol leaf and trunk bark extracts of Cordyla pinnata had similar reducing power of ferric iron $(p>0.05)$.

The reducing capacity of ferric ion seems to be related to the degree of hydroxylation and extend to the conjugation in phenolic compounds. ${ }^{11}$ Thereby the reducing power of the extracts may be due to the presence of hydroxyl groups of polyphenols (flavonoids and tannins) present in these extracts.

Indeed, polyphenolic compounds can serve as electron donors. ${ }^{12}$ Therefore, they are considered as reducing and inactivating oxidants. Other previous studies have also shown that the reducing power of a compound can serve as a significant indicator of its potential antioxidant activity. ${ }^{13}$

Antioxidant molecules such as ascorbic acid, tocopherol, flavonoids and tannins have been shown to reduce and discolor DPPH due to their ability to donate hydrogen. ${ }^{14}$

The polyphenols (tannins and flavonoids) of the leaf and trunk bark extracts of $C$. pinnata may be partly responsible for the antioxidant activity of these extracts. Indeed, polyphenols are among the most effective antioxidant phytoconstituants and many biological activities attributed to flavonoids are linked to their antioxidant property. ${ }^{15,16}$ Other studies have shown that flavonoids are good inhibitors of enzymes responsible for the production of free radicals such as xanthine oxidase, which is an important biological source of the superoxide radical. ${ }^{17,18}$ According to these studies, the antioxidant action of polyphenols is not limited only to the inhibition and deactivation of free radicals, but also to the neutralization of oxidative enzymes and the chelation of traces of metal ions inducing activated oxygen species production..$^{19,20}$

\section{CONCLUSION}

The ethanol leaf and trunk bark extracts of $C$. pinnata contained, a part of anthracenic derivatives, the same phytochemical groups. The ethanol leaf and trunk bark extracts of the plant had also shown similar activity in DPPH and FRAP assays. For the plant preservation the use of the leaf extract must be recommended in place of the trunk bark one which may lead to its rarefaction.

\section{CONFLICTS OF INTEREST}

The authors declare that there is no conflicts of interests.

\section{REFERENCES}

1. Lemmens RHMJ, Louppe $D$, Oteng-Amoako AA. Ressources végétales de I'Afrique tropicale. Bois d'œuvre. Fondation PROTA, Pays-Bas, 2012.

2. Chen $X$, Guo $C$ and Kong J. Oxidative stress in neurodegenerative diseases. Neural Regeneration Research. 2012;7(5):376-785.

3. Valko M, Leibfritz D, Moncol J, Cronin MTD, Mazur M, Telser J. Free radicals and antioxidants in normal phiosiological functions and human disease. The International Journal of Biochemistry and Cell Biology. 2007;39:44-84.

4. Joslyn MA. Methods in food analysis. Physical, chemical and instrumental methods of analysis. Academic Press, London and New York; 1970.

5. Hirano R, Sasamoto W, Matsumoto A, Itakura $H$, Igarashi O, Kundo K Antioxidant ability of various flavonoids against DPPH radicals and LDL oxidation. Journal of Nutritional Science and Vitaminology. 2001;47(5):357-62.

6. Bassene E. Initiation à la recherche sur les substances naturelles: extraction, analyses, essais biologiques. Presses Universitaires, Dakar, 2012.

7. Veitch NC, Kite GC, Lewis GP. Flavonol pentaglycosides of Cordyla (Leguminosae: Papilionoideae: Swartzieae): Distribution and taxonomic implications. Phytochemistry. 2008; 69(12):2329-35.

8. Shahidi F. Antioxidants: extraction, identification, application and efficacy measurement. EJEAF Che. 2008;7(8):3325-30.

9. Gorinstein S, Zachwieja Z, Katrich E, Pawelszik E, Homekit RR, Trakhtenberg $\mathrm{S}$, et al. Comparison of the contents of the main antioxidant compounds and the antioxidant activity of white grapefruit and the new hyrid. LebensmittelWissenschaft und-Technologie. 2004;37(3):337-43.

10. Prior RL, Wu X, Schaich K. Standardized methods for the determination of antioxidant capacity and phenolics in foods and dietary supplements. Journal of Agriculture and Food Chemistry. 2005;53(10):4290-303.

11. Benzie IF, Choi SW. Antioxidants in food: content, measurement, significance, action, cautions, caveats, and research needs. Advances in Food and Nutrition Research. 2014;71:1-53.

12. Siddhuraju $P$, Becker $K$. The antioxidant and free radical scavenging activities of processed cowpea (Vigna unguiculata (L.) Walp.) seed extracts. Food Chemistry. 2007;101(1):10-9.

13. Jeong SM, Kim SY, Kim DR, Jo SC, Nam KC, Ahn DU, et al. Effects of heat treatment on the antioxidant activity of extracts from citrus peels. Journal of Agriculture and Food Chemistry. 2004;52(11):3389-93.

14. Sindhu M, Abraham TE, Zakaria ZA. Reactivity of phenolic compounds towards free radicals under in vitro conditions. Journal of Food and Science Technology. 2015;52(9):5790-8.

15. Gee JM, Johnson IT. Polyphenolic compounds: interactions with the gut and implications for human health. Current Medicinal Chemistry. 2001; 8(11):1245-55.

16. Fuhrman B, Lavy A, Aviram M. Consumption of red wine with meals reduces the susceptibility of human plasma and low-density lipoprotein to lipid peroxidation. The American Journal of Clinical Nutrition. 1999:61(3):549-54.

17. Hanasaki $Y$, Ogawa S, Fukui S. The correlation between active oxygens scavenging and antioxidative effects of flavonoids. Free Radical Biology and Medicine. 1994;16(6):845-50.

18. Cos $P$, Ying $L$, Calomme $M$, Hu JP, Cimanga K. Structure-activity relationship and classification of flavonoids as inhibitors of xanthine oxidase and superoxide scavengers. Journal of Natural Products. 1998;61:71-6.

19. Halliwell B. Free radicals and antioxidants: updating a personal view. Nutrition Reviews. 2012,70(5):257-65.

20. Cotelle N. Role of flavonoids in oxidative stress. Current Topics in Medicinal Chemistry. 2001;1(6):569-90. 


\section{GRAPHICAL ABSTRACT}
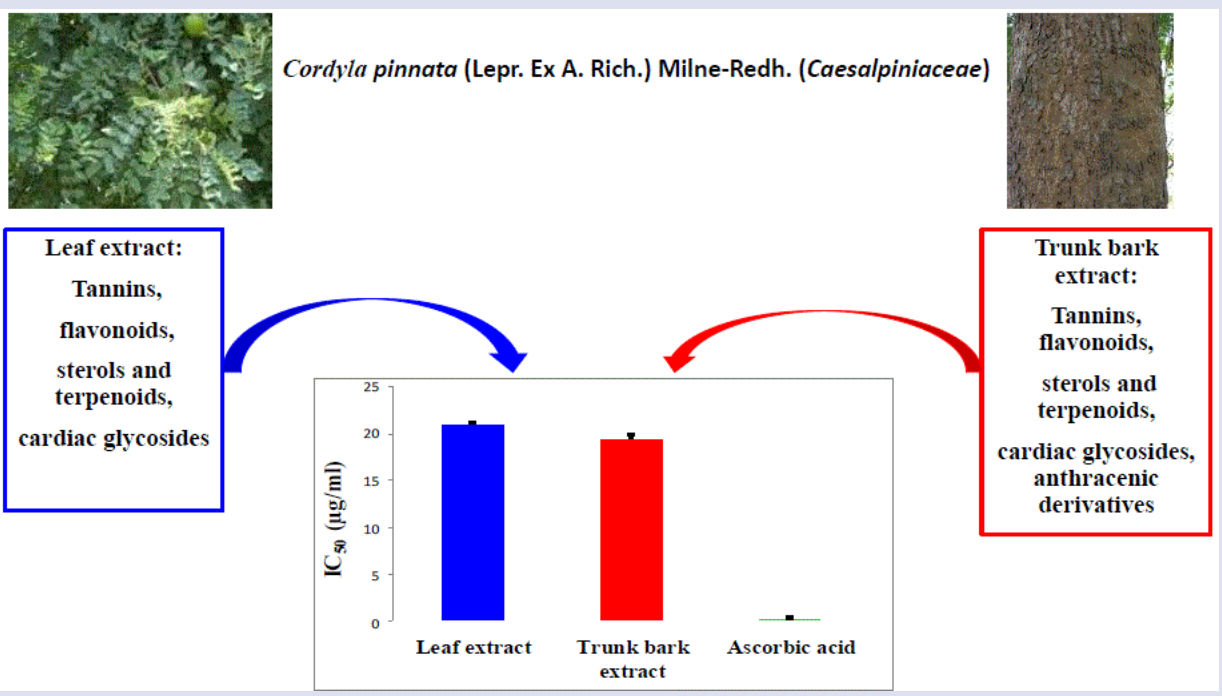

\section{ABOUT AUTHORS}
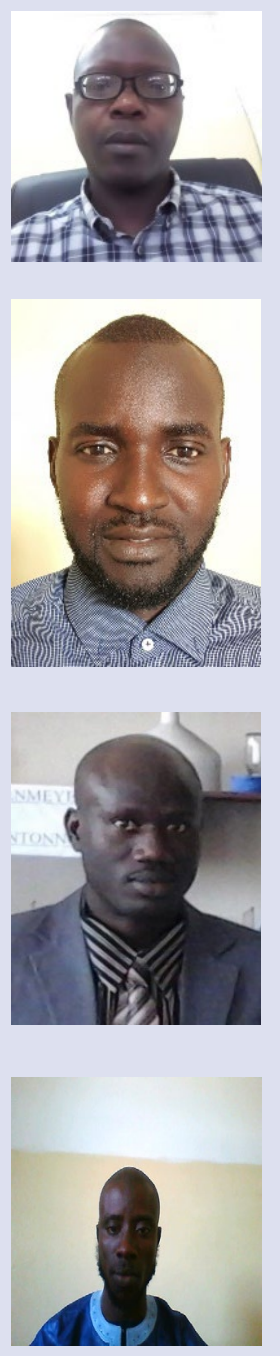

Alioune Dior Fall is a phytochemist, Associate Professor at the Laboratory of Pharmacognosy and Botany of the Faculty of Medicine, Pharmacy and Odontology of the Cheikh Anta Diop University of Dakar. He is the head of service of the Laboratory of Pharmacognosy and Botany. He holds a Doctorate of State of Pharmacy, a Master degree in Chemistry and Biochemistry of Natural Products, a Master of Taxonomy, Biodiversity, Ethnobotany and Conservation of Natural Resources obtained in Dakar. He also holds a PhD in Pharmacognosy. He has forty publications and more than thirty communications.

Serigne Ibra Mbacke DIENG is a lecturer at the Laboratory of Pharmacognosy and Botany of the Faculty of Medicine, Pharmacy and Odontology of the Cheikh Anta Diop University of Dakar. He holds a Doctorate of State of Pharmacy, a master's degree in Chemistry and Biochemistry of Natural Products, a master's degree in Biochemistry and Genetic Engineering, a master's degree in hospital pharmacy and local authorities obtained in Dakar. He sis a PhD sutudent also and has published 5 publications and done 2 communications.

Abdou SARR is a Pharmacist associated with research and teaching at the Laboratory of Pharmacognosy and Botany of the Faculty of Medicine, Pharmacy and Odontology of the Cheikh Anta Diop University of Dakar. He holds a Doctorate of State of Pharmacy, a Master degree in Chemistry and Biochemistry of Natural Products, a Master degree in Quality-Safety-Environment (QSE). He is currently doing his PhD in Drug Science, Option Pharmacognosy. He is associated with a dozen of publications.

Mbaye DIENG is a temporary assistant at the Laboratory of Pharmacognosy and Botany of the Faculty of Medicine, Pharmacy and Odontology of the Cheikh Anta Diop University of Dakar.

He holds a Master's degree in Natural Sciences, a master degree in Chemistry and Biochemistry of Natural Products. He also holds a PhD in Chemistry and Biochemistry of Natural Products and a master degreer in Biotoxicology applied to Environment, Industry and Health. He has five publications and three communications to his credit.

Cite this article: FALL AD, DIENG SIM, SARR A, DIENG M. Phytochemical Screening and Antioxidant Effect of Ethanol Leaf and Trunk Bark Extracts of Cordyla pinnata (Lepr. Ex A. Rich.) Milne-Redh. (Caesalpiniaceae). Pharmacog J. 2019;11(6)Suppl:1415-8. 